\title{
Determinants of Foreign Direct Investment (FDI) in Agriculture Sector based on Selected High-income Developing Economies in OIC Countries: An Empirical Study on the Provincial Panel Data by Using Stata, 2003-2012
}

\author{
Intan Maizura Abdul Rashid", Nor'aznin Abu Bakar, Nor Azam Abdul Razak \\ School of Economics, Finance and Banking, College of Business, Northern University of Malaysia, Malaysia
}

Copyright $(2016$ by authors, all rights reserved. Authors agree that this article remains permanently open access under the terms of the Creative Commons Attribution License 4.0 International License

\begin{abstract}
This research endeavours to set out to empirically examine the determinants of Foreign Direct Investment (FDI) in Agriculture Sector based on selected high-income developing economies in OIC countries. The agriculture sectors react as important keys in the expansion of any economy growth to eliminate the poverty issues. Therefore, it reviews the experiences of agriculture investment in selected member countries with a view to identify potential roles for countries seeking FDI and their development partners in nurturing FDI intra OIC especially in the agriculture new investment. In this study, the FDI in Agriculture Sector react as dependent variable and the independent variable economic determinant, list of market size, inflation, poverty, exchange rate and infrastructure in selected OIC Countries (Malaysia, Oman and Brunei).
\end{abstract}

Keywords OIC, FDI in Agriculture, Economic Growth, Panel Data, Poverty

\section{Introduction}

This paper reviews the agriculture sector in member countries of Organization of the Islamic Cooperation (OIC), and pays specific attention to issues of determining the potential FDI in the sector. In addition, it reviews the experiences of agriculture investment in selected member countries with a view to identify potential roles for countries seeking FDI and their development partners in nurturing FDI intra OIC especially in the agriculture new investment. Incremental on the foods price viewed during the food crisis in year 2006 until 2008 triggered several serious harmful socio-economic impacts on the economies of many developing countries, including the OIC members. In addition, it created further poverty for millions of societies who were already distress from the hunger and poverty in these countries. In high income countries, they also exposed to these crisis where inflation on price of goods and foods worsened the food security conditions. The agriculture sectors react as important keys in the expansion of any economy growth to eliminate the poverty issues. These roles are even more pronounced in low income economies where majority of the residents live in rural areas and they are rely directly, indirectly or greatly on the sector. With the sector being a vital source of employment with over 65 percent of the developing countries labor force depending on agriculture, it is not surprising that agriculture development is essential in any poverty alleviation policy. The World Bank (2014) stated the total OIC population that are still living not more than USD \$1.25 each day was about $17.4 \%$ of world total population in the year 1990 until 2011. The World Bank also indicated the poverty level of OIC countries remained comparatively very high align with their percentages over the world total poor that were also increased significantly, the world total poor recorded about $33.1 \%$ in year 2011 but only $22 \%$ in 1990 . In addition, non-monetary poverty indicators also vary among the OIC Countries for examples Human Development Index values of OIC countries are between 0.855 and 0.304 , Multidimensional Poverty Index values are between zero and 0.642 , and Global Hunger Index values are between zero and 33.6 .

\section{Literature Review}

The Eclectic Theory of FDI, which was developed by 
Dunning (1988), provides a tool to explain the influence of economic growth on FDI attraction to host countries. The dependency theory found the cause of underdevelopment to be external to the socioeconomic formations of the less developed countries. They argued that FDI not only resulted to enclave development but also diminished the possibilities of development. The dependency idea is also considered in the literature of unequal exchange. These literatures suggest that the North-South division is mainly due to structural difference, innovations in the North and initial conditions favouring the North to produce industrial goods (Krugman, 1981).

The extended Cobb Douglas production framework helps to explore the three-way linkage between the three variables: FDI inflows, poverty reduction and economic growth. It is therefore worth investigating the interrelationships between the three variables by considering them simultaneously in a modelling framework. Based on this interaction, this modelling can help policy makers to build sound economic policies to sustain economic development. Furthermore, Bruno and Easterly(1998) and Anwar and Sun (2011), among others, empirically test the impact of inflation on economic growth and these studies show that inflation has a statistical significant influence on economic growth. Further, the Cobb-Douglas agricultural production function is used in several studies e.g. to test for the effects of transportation infrastructure and electricity on the agricultural production (Fellonni et al., 2001) or to examine the governance indicators' effect (Lio and Liu, 2008).

The debate has been dominated by an orthodox perspective comprising the classical and neo classical, endogenous growth models and the development economists on one hand and the dependency theories on the other. In sum, the classical, neoclassical growth theories and the endogenous growth theories support strongly the role of FDI in promoting economic growth as well as poverty reduction in host countries. According to the classical and neoclassical theories, FDI is viewed as a way to allocate capital to a place where it is most productive and hence enhances economic growth through filling the saving investment gap. For the endogenous growth theories, FDI, in addition to filling the saving investment gap, helps as a channel to reduce poverty, transfer knowledge, promote learning by doing, and bring in technology spillovers and human capital augmentation. Consequently, FDI stimulates economic growth in host countries. The Eclectic Theory of FDI, on the other hand, provides a tool to explain the influence of economic growth on FDI attraction to host countries.

\section{Research Objectives}

The primary objective of conducting this study is to determine the determinants of foreign direct investment (FDI) in agriculture sector in high income of OIC countries. Based on the theoretical framework and research questions of this study, the research objectives of this research study had been constructed. The followings are the research objectives of this research study:

1. To investigate the relationship between exchange rate and foreign direct investment (FDI) in agriculture sector of OIC high-income developing economies.

2. To examine the relationship between poverty and foreign direct investment (FDI) in agriculture sector of OIC high-income developing economies.

3. To investigate the relationship between market size and business climate and foreign direct investment (FDI) in agriculture sector of OIC high-income developing economies.

4. To examine the relationship between inflation and foreign direct investment (FDI) in agriculture sector of OIC high-income developing economies.

5. To investigate the relationship between infrastructure and foreign direct investment (FDI) in agriculture sector of OIC high-income developing economies.

\section{Research Methodology}

A provincial panel data from 2003 to 2012 and Pooled Ordinary Least Square (POLS), Random Effects Model and Fixed Effects Model are used to estimate the economic determinant effect of FDI in agriculture. After conduct several test such as Hausmen Test and Breusch and Pagan Lagrangian Multiplier Test, Random Effects Model is considered most appropriate model to apply in this study rather than Fixed Effects Model.

\section{Theoretical Framework}

The samples to be taken in this study are based on the data, from the year of 2003 to 2012 . The availability of data is one of the justifications behind choosing these periods. The variables that have been taken as the independent variable are exchange rate, labor cost, market size, inflation, infrastructure and last but not less economic growth, whereas the dependent variable is foreign direct investment. The sample of data that has been taken for empirical analysis will take credit on 10 years data in annually basis.

\section{Data Collection Methods}

Table 1. Unit Measurement for all variables

\begin{tabular}{|c|c|c|c|}
\hline Variable & Abbreviation & Unit of Measurement & Sources \\
\hline Foreign Direct Investment in agriculture & FDI & FDI in agriculture sector (USD) & FOA \\
\hline Exchange Rate & EXC & Inflation, GDP deflator (annual \%) & World Bank Data, Central Bank \\
\hline Market Size & GDP & GDP per capita growth (annual \%) & World Bank Data, Central Bank \\
\hline Poverty & POVT & Head counts & World Bank Data \\
\hline Inflation & INFL & Inflation Rate & World Bank Data, Central Bank \\
\hline Infrastructure & INFREX & Infrastructure Index & World Bank Data \\
\hline
\end{tabular}




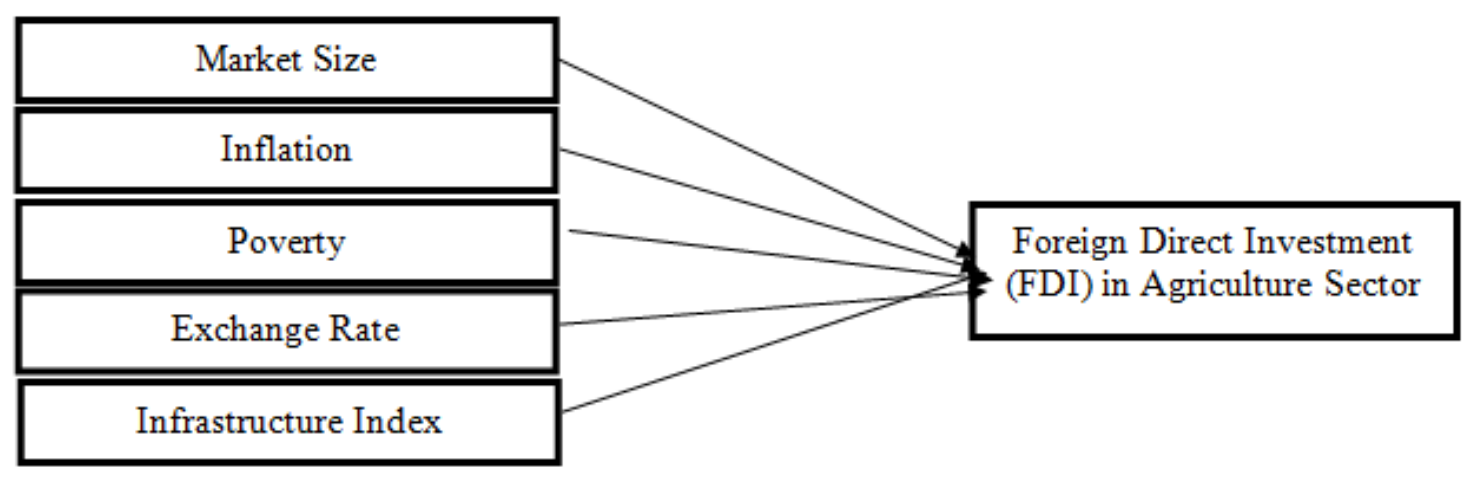

Independent variables

Dependent variable

Figure 1. Research Frameworks of the Determinants of Foreign Direct Investment (FDI) in Agriculture Sector among High Income Economies of OIC Countries.

\section{Research Framework}

Research framework is important in order to understand the relationship between the dependent variable and the independent variables that can affect final outcomes of a study, as shown in Figure 1, which explained about the determinants of Foreign Direct Investment (FDI) in Agriculture sector among OIC countries. A variable plays a crucial part to stimulate the research study and any other elements that contradictory rate can be taken on. The sample model used here regress Foreign Direct Investment (FDI) in Agricultural sector.

Framework,

$$
\mathrm{FDI}=\alpha+\beta_{1} \mathrm{GDP}_{\mathrm{i}}+\underset{\text { INFREX }_{\mathrm{i}}+\varepsilon_{\mathrm{i}}}{\beta_{\mathrm{INFL}_{i}}+\beta_{3} \mathrm{POVT}_{\mathrm{i}}+\beta_{4} \mathrm{EXC}_{\mathrm{i}}+\beta_{5}}
$$

Based on the equation (1), the positive sign of GDP, INFL, POVT, EXC and INFREX coefficients represent positive effects of market size, inflation rate, poverty, exchange rate and infrastructure index on foreign direct investment in agriculture sector among OIC countries. A rise in GDP, INFL, POVT, EXC and INFREX will cause the FDI to decrease in agriculture sector in OIC countries, and vice versa.

\section{Findings and Conclusion}

First of all, Panel Data Analysis that including Random Effects Method is used for the variation across entities is assumed to be random and uncorrelated with the predictor or independent variables included in the model. Fixed Effects Method used in analysing the impact of variables that vary over the time. Pooled OLS Method is if the individual effect does not exist, ordinary least square (OLS) produces efficient and consistent parameter estimates. Generalize Least Squares (GLS) Method based on constructing an approximate covariance estimates for the log relative risks and estimating a corrected linear trend. Next is the Hausmen Test that is if find both significant level of the Random and Fixed Effects Method that going to determine which is the better than others by comparing between the Fixed and Random Effects Method. These entire tests are performed and findings of this research are based on the data that has been run by using the application called STATA.

\section{Descriptive Statistic Analysis}

Descriptive Statistic Analysis is for the data analysis that stated the number of the observation that is part required to make the observation based on the data that being collected. The analysis performed by the descriptive statistic to find out the statistic of the every of the variables involved which FDI, market size, inflation, poverty, exchange rate, and infrastructure index. Then, it also included mean of the each data of the variable and included the standard deviation square root of the mean. Besides that it also have the minimum and maximum value of the data that being run.

Table 2. Descriptive Statistics of Determinants and FDI

\begin{tabular}{|c|c|c|c|c|c|}
\hline & Obs & Mean & Std. Dev. & Min. & Max \\
\hline FDI & 30 & 5.10 & 15.99 & 0.00 & 98.5 \\
\hline GDP & 30 & 113640.10 & 101071.60 & 6557.33 & 462979.20 \\
\hline INFL & 30 & 6.55 & 5.38 & 0.20 & 20.30 \\
\hline POVT & 30 & 1.88 & 2.13 & 167545.00 & 6.38 \\
\hline EXC & 30 & 69.68 & 72.36 & 0.38 & 219.59 \\
\hline INFREX & 30 & 2.20 & 2.23 & 0.00 & 5.70 \\
\hline
\end{tabular}

Based on the table above all the variables are having range 30 observations. The GDP have the highest mean and standard deviation of 113640.10 and 101071.60 respectively in the data distribution. The poverty has the lowest value of the mean and standard deviation that is 1.88 and 2.13. Next the other variables having the middle range between the GDP and POVT. The FDI mean and standard deviation is 5.10 and 15.99 , the INFL mean and standard deviation is 6.55 and 5.38, the EXC is 69.68 and 72.36 for the mean and standard deviation. Lastly, the INFREX with 2.20 and 2.23 for the mean and standard deviation. The table also show the minimum and maximum value of the each variable that being presented. The market size which is the GDP is highest of the minimum and maximum value that is 6557.33 and 462979.20. The lowest maximum value is the infrastructure index that is 5.70. Then the POVT minimum and maximum value is the 167545.00 and 6.38. The exchange rate is EXC that is 0.38 and 219.59 for the minimum and maximum value. 
480 Determinants of Foreign Direct Investment (FDI) in Agriculture Sector based on Selected High-income Developing Economies in OIC Countries: An Empirical Study on the Provincial Panel Data by Using Stata, 2003-2012

Last variable that is infrastructure index represented by the INFREX having the minimum and maximum value is 0.00 and 5.70 .

\section{Correlation of Variables in Study}

The correlation of variables is the relationship between each variables included the dependent variable and independent variable that being analysis in the research.

The existence of high correlation among the independent variables will lead to the problem of multi-collinearity in the estimation. Still consider these variables because of the panel data estimation which takes care of the collinearity problems. The highest value of the correlation means the very good relationship between the two variables in this research. It also shows that between two variables got the aspect that being connected that can be used for the research in the future. Based on the table above the correlation among the variables is stated by the value for each variables between others variables. The highest correlation rate is the exchange rate as EXC and the inflation as INFL is the 0.7304. It is shows that between this two variables got very strong relationship or correlation. The another good relationship between two variables is the labour cost as POVT with market size as GDP and POVT with inflation as INFL that the value is above 0.5 it is 0.5814 and 0.5546 . Then the range value of the correlation 0.20 to 0.49 that being consider as the good correlation value that is the market size as GDP with foreign direct investment as FDI is 0.2571, infrastructure index as INFREX with market size as GDP is 0.3975. Next in the table 4.3.1 also having being conclude having the poor relationship or correlation between two variables in this research. The range value of poor correlation value is below than 0.01 or the negative value. It show to the variables inflation as INFL with foreign direct investment as FDI value is -0.1330 , the poverty with foreign direct investment as FDI value is -0.0611 , the exchange rate as EXC with foreign direct investment as FDI values is -0.2244 , the infrastructure index as INFREX with inflation as INFL value is -0.0611 , the infrastructure index as INFREX with exchange rate as EXC value is -0.3146 .

Table 3. Correlation of variables in study

\begin{tabular}{|c|c|c|c|c|c|c|}
\hline & LFDI & LGDP & INFL & LPOVT & LEXC & \\
\hline LFDI & 1 & & & & \\
\hline LGDP & 0.2571 & 1 & 1 & & \\
\hline INFL & -0.1330 & 0.1979 & 0.5546 & 1 & \\
\hline LPOVT & -0.0611 & 0.5814 & 0.7304 & 0.3118 & \\
\hline LEXC & -0.2244 & 0.0657 & -0.0611 & 0.0315 & 1 \\
\hline INFREX & 0.1479 & 0.3975 & -0.3146 & \\
\hline
\end{tabular}

Table 4. Determinants of FDI inflows: Panel data Estimation Results based on Random Effects (RE) and Fixed Effects (FE)

\begin{tabular}{|c|c|c|c|c|c|c|}
\hline \multirow{2}{*}{ Variables } & \multicolumn{3}{|c|}{$\mathrm{RE}$} & \multicolumn{3}{|c|}{$\mathrm{FE}$} \\
\hline & Coeff. & t-Statistic & $P$ value & Coeff. & t-Statistic & $\mathrm{P}$ value \\
\hline GDP & $0.0001 * *$ & 1.36 & $0.175 * *$ & 0.0002 & 0.63 & 0.549 \\
\hline INFL & 0.5827 & 0.87 & 0.383 & 0.5381 & 0.82 & 0.444 \\
\hline POVT & $-2.7807 *$ & -1.27 & $0.205^{*}$ & -8.4008 & -0.18 & 0.860 \\
\hline EXC & -0.0715 & -1.09 & 0.277 & -0.0556 & -0.53 & 0.616 \\
\hline INFREX & -0.8005 & -0.88 & 0.376 & -0.2897 & -0.57 & 0.586 \\
\hline Adj. $\mathrm{R}^{2}$ & \multicolumn{3}{|c|}{0.5552} & \multicolumn{3}{|c|}{0.3867} \\
\hline
\end{tabular}

Note: $* * *, * * *$ are significant respectively to $\mathrm{p}<0.05, \mathrm{p}<0.01$ and $\mathrm{p}<0.001$

\section{Random and Fixed Effects Method}

The Random Effects Method is the method that the variation across entities is assumed to be random and uncorrelated with the predictor or independent variables included in the model. Advantages of the Random Effects are that can include time invariant variables. The Fixed Effects Method is to explore the relationship between predictor and outcome variables. Each entity has its own individual characteristic that may or may not influence the opinion.

In this table in also include the coefficient, t-statistic value and $P$ value that want to determine which of the variables is acceptable using the Random Effects Method or the Fixed Effects Methods. The value for t-Statistic being rejected is above 1.96 that mean below than 1.96 is acceptable. The value for $\mathrm{P}$ value being rejected in the below than 0.05 that mean any value is higher than 0.05 being acceptance. Start with the market size as GDP at the RE method the t-statistic value is 1.36 and $P$ value is 0.175 , the FE method t-statistic and $P$ value is 0.63 and 0.549 it is shows that GDP is being acceptance. Next is the independent variables of inflation as at the RE method the t-statistic and P value is the 0.87 and the FE method the t-statistic and $\mathrm{P}$ value is the 0.82 and 0.444 , it is shows that inflation variables is being acceptance. Then, the poverty show by the RE method the $t$-statistic and $P$ value is -1.27 and 0.205 and the FE method t-statistic and $\mathrm{P}$ value is -0.18 and 0.860 , it is show that poverty variables is being acceptance by the two methods. exchange rate as EXC also one of the ndent variables at the RE method the t-statistic and $\mathrm{P}$ 0.277 and the FE method the t-statistic and $\mathrm{P}$ value is -0.53 and 0.616 , it is shows that the variables is being acceptance. Lastly, the infrastructure index variables as INFREX at the RE method the t-statistic and P value is -0.88 and 0.376 and FE method the t-statistic and $P$ value is -0.57 and 0.586 , it is shows the variables is being acceptance. The adjust $\mathrm{R}^{2}$ value for the RE method is 0.5552 and FE method is 0.3867 . 
Table 5. The Hypothesis Statement

\begin{tabular}{|c|c|c|}
\hline No of Hypothesis & Statement of Hypothesis & Results \\
\hline H1 & $\begin{array}{c}\text { There is a relationship between exchange rate and foreign direct investment (FDI) in agriculture } \\
\text { sector of OIC high-income developing economies of OIC countries. }\end{array}$ & Rejected \\
\hline H2 & $\begin{array}{c}\text { There is a relationship between poverty and foreign direct investment (FDI) in agriculture sector } \\
\text { of OIC high-income developing economies of OIC countries. }\end{array}$ & Accepted \\
\hline H3 & $\begin{array}{c}\text { There is a relationship between market size and foreign direct investment (FDI) in agriculture } \\
\text { sector of OIC high-income developing economies of OIC countries. }\end{array}$ & Accepted \\
\hline H4 & $\begin{array}{c}\text { There is a relationship between inflation and foreign direct investment (FDI) in agriculture sector } \\
\text { of OICh-income developing economies of OIC countries. }\end{array}$ & Rejected \\
\hline H5 & $\begin{array}{c}\text { There is a relationship between infrastructure and foreign direct investment (FDI) in agriculture } \\
\text { sector of OIC high-income developing economies of OIC countries. }\end{array}$ & Rejected \\
\hline
\end{tabular}

\section{Hypothesis Results}

The empirical results show that highly important in policy implementation that were related to the explanatory variables have significant effect on FDI in agriculture sector. Based on the empirical results, the government should be focused and paid attention all the determinants, particularly for reduction of poverty and market size of agriculture sector. These two determinants were the most significant with the foreign direct investment in agriculture sector in OIC countries. There is no doubt that poverty played a huge role in FDI in agriculture sector as poverty has been considered as the most important factor whenever investors are coming to bring in investment into OIC countries. If the poverty in one country is being too high, it is hard to convince foreign investors to cash in into the agriculture sector in OIC countries. Nevertheless, the minimum wage policy should be well managed by the OIC countries government whereby reduce in poverty cause a slump in the amount of FDI inflows in agriculture sector in OIC member countries. The implementation of minimum wage policy by the government is nevertheless that crucial.

\section{REFERENCES}

[1] Abd Halim Ahmad, N. A. (2013). Investigation of optimal capital structure in Malaysia: a panel threshold estimation. Studies in Economics and Finance, 108 - 117.

[2] Abdoli, K. K. (2010). The citation impact of Open Access agricultural research. Online Information Review, 772 - 785.

[3] Hung, T. H. (2006). Attracting FDI in agriculture and rural development- status and solutions for improvement. Policy Advisory Briefing.
[4] Kler, P. (2007). A panel data investigation into over education among tertiary educated Australian immigrants. Journal of Economic Studies, 179 - 193.

[5] Saiful Arif Abdullaha, N. N. (2008). Changes in agricultural landscape pattern and its spatial relationship with forestland in the State of Selangor, peninsular Malaysia. Landscape and Urban Planning, 147-155.

[6] Sam, A. G. (2010). Nonparametric estimation of market risk: an application to agricultural commodity futures. Agricultural Finance Review, 285 - 297.

[7] Tang, L. (2009). A Study on Foreign Direct Investment Agriculture in China. International Journal of Business and Management.

[8] UNCTAD.2007.Best practices for organic policy. UNEP-UNCTAD Capacity Building Task Force on Trade, Environment and Development (available at http://www.une p.ch/etb/publications/UNCTAD_DITC_TED_2007_3.pdf).

[9] UNCTAD (1994). World Investment Report: Transnational Corporations, Employment and the Workplace, New York: United Nations.

[10] UNCTAD (1998). World Investment Report: Trends and Determinants, New York and Geneva: United Nations.

[11] UNCTAD (2007). World Investment Report: Transnational Corporations, Extractive Industries and Development. New York and Geneva: United Nations. Retrieved on July15, 2008 from http://www.conapri.org/download/wir2007_en.pd $\mathrm{f}$

[12] World Bank Agriculture and Rural Development Department, World Bank, Agricultural \&Rural Development Department, Washington, D.C. World Bank (2013), A Unified Approach to Measuring Poverty and InequalityTheory and Practice,

[13] World Bank, Washington, D.C. World Bank (2014), Knowledge in Development Note: Measuring Global Poverty. Available at: http://bit.ly/1vUPbSJ 